\title{
HUBUNGAN TINGKAT PENDAPATAN DENGAN TINGKAT KONSUMSI MASYARAKAT DI KECAMATAN BONTONOMPO KABUPATEN GOWA
}

\author{
Muhammad Ikram ${ }^{1}$ Sanusi AM $^{2}$ Ansar $^{3}$ \\ Ilmu Ekonomi Studi Pembangunan Fakultas Ekonomi Dan Bisnis \\ Universitas Muhammadiyah Makassar \\ (ikram@unismuh.ac.id)
}

\begin{abstract}
ABSTRAK
Tujuan penelitian ini adalah untuk menjelaskan hubungan tingkat pendapatan dengan tingkat konsumsi masyarakat di Kecamatan Bontonompo Kabupaten Gowa. Penelitian ini mengunakan data time series yang diperoleh dari Badan Pusat Statistik (BPS). Alat analisis yang digunakan adalah rumus korelasi Pearson dengan bantuan SPSS For Windows Release 16. Hasil penelitian menyimpulkan bahwa tingkat pendapatan memiliki hubungan yang signifikan terhadap tingkat pendapatan masyarakat di Kecamatan Bontonompo Kabupaten Gowa. Diharapkan pemerintah Kabupaten Gowa dapat mengupayakan programprogram yang dapat mendorong terciptanya lapangan kerja yang lebih banyak dan beragam agar masyarakat tiap kacamatan bias mempemperoleh pendapatan yang layak dan memenuhi kebutuhan konsumsinya.
\end{abstract}

Kata Kunci: Pendapatan, Konsumsi

\section{ABSTRACT}

The purpose of this study is to explain the relationship between the level of income with the level of public consumption in District Bontonompo Gowa District. This research uses time series data obtained from Central Bureau of Statistics (BPS). The analytical tool used is Pearson correlation formula with the help of SPSS For Windows Release 16. The results concluded that the income level has a significant relationship to the level of public income in District Bontonompo Gowa Regency. It is expected that the Gowa Regency government can pursue programs that can encourage the creation of more and more diverse employment so that the communities of each bias can earn a decent income and meet their consumption needs.

Keywords: Revenue, Consumption

\section{PENDAHULUAN}

\section{Latar Belakang}

Teori ekonomi makro menjelaskan, bahwa konsumsi tergantung dari berbagai faktorseperti pendapatan, kebijaksanaan financial perusahaan, distribusi pendapatan nasional, sikap dan harapan serta berbagai faktor lainnya. Namun kenyataan yang terlihat dalam masyarakat di Negara yang sedang berkembang seperti di Indonesia misalnya,maka terlihat bahwa pendapatan yang paling berpengaruh dalam menentukan konsumsi tergantung dari naik turunya pendapatan yang dalam istilah ekonomi dikenal sebagai fungsi konsumsi. Pada 
umumya masalah yang dihadapi oleh negara yang sedang berkembang adalah masalah rendahnya tingkat pendapatan masyarakat pada umunya.

Hal ini erat dengan pertumbuhan penduduk yang begitu cepat dimana tidak diimbangi dengan perluasan kerja yang dapat menyerap angkatan kerja yang ada, maka akan menambah jumlah pengangguran yang dapat menyebabkan kemiskinan semakin luas. Di Kecamatan Bontonompo, Kabupaten Gowa yang merupakan bagian dari wilayah Provinsi Sulawesi Selatan dalam kaitan ini tentunya tidak akan terlepas dari masalah-masalah yang dihadapi oleh masyarakat Indonesia pada umunya. Hal ini dilihat bahwa jika dibandingan dengan negara yang sudah maju, maka tingkat konsumsi masyarakat yang ada rendah. Hal ini disebabkan oleh besarnya tingkat pendapat masyarakat dikategorikan masih rendah sehingga pola konsumsi pada umunya hanya memenuhi kebutuhan pokok. Ini berarti bahwa taraf hidup masyarakat yang ada masih dibawah standar yang diharapkan karena hal ini merupakan salah satu ciri dari negara berkembang.

Pola semacan tersebut diatas timbul sebagai akibat adanya serangkaian keganjilanserta berbagai ketimpangan yang merupakan yang saling mempengaruhi satu sama lain. Ketimpanganyang dimaksud adalah keganjilan dalamperimbangan antara faktor-faktor produksi yang tersedia dalam masyarakat, kepincangan dalam pendapatan. Di antara golongan masyarakat dan adanya kelemahan pada kelembagaan masyarakat dan pola sifat kebijaksanaan hidup masyarakat itusendiri. kepincangan dan keganjilan diatas saling berkaitan erat sehingga usaha untuk menanggulangi diperlukan adanya berbagai usaha yang dilakukan secara menyeluruh dan terpadu. Berbagai kebijaksanaan pemerintah yang bersifat operasionalsangat diperlukan untuk menanggulangi kelemahan atau ketimpangan tersebut agar supaya masyarakat dapat terhindarkan.

Kaitanyan dengan dikecamatan Bontonompo Kabupaten Gowa merupakan daerah potensial namun adanya ketimpangan keganjilan yang turut berpengaruh maka peranan pemerintah sangat diharapkan untuk melakukan berbagai kegiatan terpadu seperti, peningkatan sarana prasarana perhubungan, pendidikan, industri serta berbagai kebijaksanaan lainnya, sehingga berbagai kebijaksanaan yang dapat dikurangi bahkan dihapuskan. Dengan adanya kebijaksanaan yang dapat memberikan perubahan maka diharapkan kegiatan produksi dan distribusi masyarakat dapat berjalan dengan baik. Hal ini yang 
Jurnal Ekonomi Balance Fakultas Ekonomi Dan Bisnis

Volume 11 No 1 Tahun 2015

ditentukan maka dapat lapangan kerja yang baru serta berbagai peningkatan diberbagai sector kegiatan, dimana dikecamatan Bontonompo Kebupaten Gowa sebagai daerah yang letak geografisnya sehingga dapat meningkatkan pendapatanya yang tentunya akan menaikan konsumsinya yang pada akhirnya akan merubah pola tingkat konsumsi yang ada sesuai dengan apa yang diharapkan. Berdasarkan kesan dan harapan seperti tersebut diatas serta keingintahuan tentang seberapa jauh hubungan tingkat pendapatan dan tingkat konsumsi yang ada pada masyarakat.

\section{TINJAUAN PUSTAKA}

\section{Pendapatan}

Pendapatan adalah sama dengan pengeluaran. Pendapatan yang dicapai olehjangka waktu tertentu senantiasa sama dengan pengeluaran jangka waktu tersebut.Pendapatanharus senantiasa sama dengan pengeluaran karena kedua istilah yang menunjutkan hal yang sama hanya dipandang dari sudut pandang lain (Winardi, 2007). Makin tinggi pendapatan perseoranganakan makin sedikit anggota masyarakat yang memilikinya, yang terbanyak menempati ruangan pendapatan yang rendah. Besarnya pendapatanproduktif dari atau faktor yang bersangkutan dalam proses produksi (Kalsan, 2009).

Perbedaan dalam tingkat pendapatan adalah disebabkan oleh adanya perbedaan dalam bakat, kepribadian, pendidikan, latihan dan pengalaman. Ketidaksamaandalam tingkat pendapatan yang disebabkan oleh perbedaan halhal ini biasanya dikurangi melalui tindakan-tindaakan pemerintah yaitu melalui bantuan pendidikan seperti beasiswa dan pemberian bantuan kesehatan.Tindakan-tindakan pemerintah cendurung menyamakan pendapatan riil. Pendapatan uang adalah upah yang diterima dalam bentuk rupiah dan sen. Pendapatan riil adalah upa yang diterima dalam bentuk barang/jasayaitu dalambentuk apa atau berapa banyak yang dapat dibeli dengan pandangan uang itu. Yang termasuk pendapatan riil adalah keuntungan-keuntungan tertentu seperti jaminan pekerjaan, harapan untuk memperoleh pendapatan tambahan, bantuan pengankutan, makan siang, harga diri yangdikaitkan dengan pekerjaa, perumahan, pengobatan fasilitas lainnya.( sofyan, 2007).

Besarnya pendapatan seeorang akan tergantung pada besarnya bantuan produktif dari orang atau faktor yang bersangkutan dalam proses produksi atau setidaknya dapat menutupi kebutuhan keluarganya. Tetapi tingkat pendapatan 
Jurnal Ekonomi Balance Fakultas Ekonomi Dan Bisnis

Volume 11 No 1 Tahun 2015

seseorang berbedamenurut jenis dan prestasi kerjanya masing-masing. Jenis dan prestasi kerja.

Pendapatan dapat diperoleh dengan memulai melakukan usaha atau kegiatan yang dapat mengahasilkan pendapatan itu sendiri.Setiap orang menghendaki agar memperoleh pendapatan yang tinggi atau setidaknyadapat menutupi kebutuhankeluarganya.Tetapi tingkat pendapatan seseorangberbeda menurut jenis dan prestasi kerjanya masing-masing.Jenis dan prestasi kerja seseorangjuga berbeda menurut kemampuan. Kaeahlian dan di tambah kecakapan serta keuletan akan lebih mudah memperoleh kesempatan kerja yang lebih cepatmemperoleh prestasi dalam bekerja, baik sebagai pegawai negri, pengusaha, petani dan pedagang. Karena semua faktor tersebut sangat mempengaruhikeberhasilan seseorang yang pada akhirnya mempengaruhi pula tingakt pendapatan.

Sebagaimana yang dikemukakan oleh suprihatinm (2005) bahwa faktorfaktor yang mempengaruhi pendapatan seseorang adalah sebagi berikut :

1. Kesempatan kerja yang tersedia

2. Kecakapan dan keahlian dalam bekerja

3. Kekayaan yang dimiliki

4. Keahlian dan keuletan berusaha

5. Banyak setidaknya modal yang dimiliki

Terbentuknya komponen kesempatan bekerja bagi semua penduduk akan membawa pengaruh terhadap pertumbuhan ekonomi suatu bangsa sebagaimana telah dikemukakan untuk melihat pertumbuhan ekonomi suatu negara dapat dilihat tingkat pendapatan perkapita masyarakat itu sendiri. Semakin tinggi pendapatan yang diterima oleh masyarakat, maka semakin baik pertumbuhan ekonomi suatu negara. pertumbuhan pendapatan seseorang juga tidak dapat dipisahkan dari kecakapan dan kehlian bekerja baik dalam bidang industri, pertanian, jasa dan berbagai sektor lainnya. Untuk itu seseorang memerlukan skiil dalam bekerja dari pekerjaan tersebut mereka akan mendapat upah dalam jumlah yang besar. Upah yang diterima juga dikatakan pendapatan seseorang.

Faktor ketiga yang mempengaruhi pendapatan seseorang adalah keahlian dan keuletan dalam berusaha.Ketabahan dan keuletan merupakan kunci sukses dalam melakukan kegiatan usaha yang pada akhirnya dengan keuletan dan ketabahan tersebut seseorang mampu memperoleh pendapatan maksimal. 
Tinggi rendah pendapatan seseorang juga dipengaruhi kekayaan miliknya. Pendapatan tersebut menunjutkan bahwa kesempurnaan modal yang dimiliki dalam kegiatan usaha merupakan suatu alterntif dalam meningkatkan volume kegiatan usaha dan tingkat pendapatan melalui kekayaan yang dimiliki oleh seseorang sehingga dapat melaksanakan berbagai jenis kegiatan usaha yang bersifat produktif yang mempunyai penghasilan yang maksimal.

Banyaknya faktor modal yang dimiliki juga berpengaruh terhadap pendapatan yang diperoleh seseorang.modal merupakan urat nadi dalam kegiatan usaha baik pada suatu perusahaan maupun bagi petani. Kedudukan modal sangat penting sekali sebagai salah satu sarana penunjang dalam melakukan berbagai kegiatan atau usaha yang bertujuan mencari keuntungan.

\section{Konsumsi}

Konsumsi merupakan salah satu komponen pendapatan nasional.Fungsi konsumsi adalah sebuah fungsi yang menghubungkan laju pengeluaran konsumsi dengan tingkat produksi nasional atau pendapatan nasional. Di duga bahwa dengan bertambahnya pendapatan nasional akan bertambah pula jumlah konsumsi. Penelitian ini memperlihatkan bagaimanabelanja ini berubah-ubah sesuai dengan naik turunya pendapatan keluarga. Penelitian yang sudah ada di indonesia adalah perubahan proporsi belanja makanan dana bukan makanan dari seluruh jumlah uang yang dibelanjakan. Selanjutnya dari angka-ngka pendapatan nasional juga kita dapat memperoleh gambaran perubahan konsumsi ini (partadierja, 2010).

Sukirno (2005), mengemukakan konsumsi merupakan belanja yang dilakuakan oleh rumah tangga ke atas barang-barang akhir dan jasa-jasa dengan tujuan untuk memenuhi kebutuhan dari orang yang melakukan perbelanjaan masyarakat ke atas makanan, pakaian dan barang-barang kebutuhan $\mathrm{n}$ yang lain digolongkan keatas perbelanjaan atau pengeluaran konsumsi. Barang yang diproduksikan khusus untuk dipergunakan oleh masyarakat untuk memenuhi kebutuhanya dinamakan barang konsumsi.

\section{METODE PENELITIAN}

Penelitian ini mengunakan data time series yang diperoleh dari Badan Pusat Statistik (BPS)di Kecamatan Bontonompo Kabupaten Gowa dengan sampel 50 rumah tangga dengan menggunakan rumus Korelasi mengolah data yaitu menggunakan Analisis Korelasi Peason untuk mengetahui hubungan 
antarvariabel dengan bantuan SPSS For Windows Release 16 dengan rumus korelasi dari Hartono (2004) adalah sebagai berikut

$$
r=\frac{n \sum X Y-\left(\sum X\right)\left(\sum Y\right)}{\sqrt{\left\{n \sum X^{2}-\left(\sum X\right)^{2}\right\}} \sqrt{\left\{n \sum Y^{2}-\left(\sum Y\right)^{2}\right\}}}
$$

Keterangan:

$r=$ Koefisien Korelasi

$\mathrm{n}=$ Jumlah Rumah Tangga

$\mathrm{X}=$ Pendapatan Masyarakat

$\mathrm{Y}=$ Konsumsi Masyarakat

PEMBAHASAN DAN HASIL

\section{Tingkat Pendapatan masyarakat}

Distribusi frekuensi tingkat pendapatan masyarakat di Kecamatan Bontonompo Kabupaten Gowa. Tabel Distribusi Frekuensi Tingkat Pendapatan Masyarakat di Kecamatan Bontonompo Kabupaten Gowa

\begin{tabular}{|l|c|c|}
\hline \multirow{2}{*}{ Interval Tingkat Pendapatan } & \multicolumn{2}{|c|}{ Frekuensi } \\
\cline { 2 - 3 } & Absolut & Relatif (\%) \\
\hline $300.000-1.300 .000$ & 24 & 48 \\
\hline $1.300 .000-2.350 .000$ & 8 & 16 \\
\hline $2.400 .000-3.400 .000$ & 6 & 12 \\
\hline $3.450 .000-4.450 .000$ & 10 & 20 \\
\hline$>4.450 .000$ & 2 & 100 \\
\hline Jumlah & 50 & 4 \\
\hline
\end{tabular}

Sumber : Data primer

Dari tabel diatas terlihat bahwa tingkat pendapatan masyarakat Kecamatan Bontonompo Kabupaten Gowa bervariasi antara 300.000 sampai dengan 5.300.000 per bulan . dari 50 responden sampel masyarakat yang diteliti, 24 responden atau 48\% menghasilkan tingkat pendapatan sebesar Rp. 300.000 sampai dengan 1.30.000 per bulan, 10 responden atau $20 \%$ menghasilkan tingkat pendapatan ebesar Rp 3.450 .000 sampai dengan 4.450 .000 per bulan, 8 responen atau $16 \%$ menghasilkan tingkat pendapatan sebesar $\mathrm{Rp} 1.300 .000$ sampai dengan 2.350 .000 per bulan, 6 responden atau $12 \%$ mengahasilan tingkat pendapatan sebesar Rp 2.400.000 sampai dengan 3.400.000 per bulan, 2 responden atau 4\% menghasilkan tingkat pendapatan sebesar > Rp. 4.450 .000 per bulan. 
Jurnal Ekonomi Balance Fakultas Ekonomi Dan Bisnis

Volume 11 No 1 Tahun 2015

\section{Tingkat Konsumsi Masyarakat}

Distribusi Frekuensi Tingkat Konsumsi Masyarakat di Kecamatan Bontonompo Kabupaten Gowa. Tabel Distribusi Frekuensi Tingkat Konsumsi Masyarakat di Kecamatan Bontonompo Kabupaten Gowa

\begin{tabular}{|c|c|c|}
\hline \multirow[t]{2}{*}{ Interval Tingkat Pendapatan } & \multicolumn{2}{|c|}{ Frekuensi } \\
\hline & Absolut & Relatif (\%) \\
\hline $300.000-1.000 .000$ & 22 & 44 \\
\hline $1.050 .000-1.800 .000$ & 9 & 18 \\
\hline $1.850 .000-2.600 .000$ & 7 & 14 \\
\hline $2.650 .000-3.400 .000$ & 10 & 20 \\
\hline$>3.400 .000$ & 2 & 2 \\
\hline Jumlah & 50 & 100 \\
\hline
\end{tabular}

Sumber : Data primer

Dari tabel diatas terlihat bahwa tingkat konsumsi masyarakat Kecamatan Bontonompo Kabupaten Gowa bervariasi antara 250.000 sampai dengan 5.300.000 per bulan . dari 50 responden sampel masyarakat yang diteliti, 22 responden atau 44\% menghasilkan tingkat konsumsi sebesar Rp. 250.000 sampai dengan 1.000 .000 per bulan, 10 responden atau $20 \%$ menghasilkan tingkat konsumsi sebesar Rp 2.650.000 sampai dengan 3.400 .000 per bulan, 9 responen atau 18\% menghasilkan tingkat konsumsi sebesar $\mathrm{Rp} 1.050 .000$ sampai dengan 1.800 .000 per bulan, 7 responden atau $14 \%$ mengahasilan tingkat konsumsi sebesar Rp 1.800 .000 sampai dengan 2.600 .000 per bulan, 2 responden atau $2 \%$ menghasilkan tingkat konsumsi sebesar > Rp. 3.400 .000 per bulan. Dari hasil penelitian terhadap tingkat pendapatan daengan tingkat konsumsi sebagai berikut :

\section{Uji Korelasi}

Untuk mengetahui hubugan tingkat pendapatan dengan tingkat konsumsi masyarakat di Kecamatan Bontonompo Kabupaten Gowa maka dilakukan teknik korelasi linear. Hubungan antar tingkat pendapatan dengan konsumsi sangat erat kaitanya yaitu masyarakat yang mempunyai tingkat pendapatan yang rendah tentu dengan sendirinya mempunyai pengeluaran konsumsi yang lebih rendah demikian pula sebaliknya yaitu bila pendapatan masyarakat besar maka peluang tingkat konsumsinya akan besar. Hal ini menunjutkan bahwa pendapatan merupakan variabel yang sangat penting dalam menetukan besar - keilnya pengeluaran konsumsi. 
Sejalan dengan itu perguson dalam juanita (2007), bahwa pendapatan adalah merupakan faktor yang menentukan konsumsi pada hal lain ia mengemukakan bahwa tingginya pendapatan bukan hanya konsumen mengeluarkan untuk beberapa barang saja, tetapi konsumen juga mengeluarkan sebagian uangnya untuk keperluaan rekreasi, kesehatan, barang-brang LUX dan kebutuhan umum lainnya. Dengan demikian kesimpulan adalah jika makin tinggi pendapatan masyarakat tersebut maka kesempatan baginya untuk memcapai kesejahteraan akan lebih banyak dibanding Orang yang rendah pendapatanya.

Jelaslah bahwa adanya kecenderungan masyarakat untuk mengeluarkan pendapatanya untuk kebutuhan konsumsi yang banyak ditentukan oleh besar kecilnya tingkat pendapatan.

\section{Correlations}

\begin{tabular}{|c|c|c|c|}
\hline & & $\begin{array}{c}\text { pendapatan } \\
\text { masyarakat } \\
(\mathrm{Y})\end{array}$ & $\begin{array}{c}\text { Konsumsi } \\
\text { Masyarakat }(\mathrm{X})\end{array}$ \\
\hline $\begin{array}{l}\text { pendapatan } \\
\text { masyarakat }(\mathrm{Y})\end{array}$ & $\begin{array}{l}\text { Pearson } \\
\text { Correlation } \\
\text { Sig. (2-tailed) } \\
\mathrm{N}\end{array}$ & $\begin{array}{r}1 \\
50\end{array}$ & $\begin{array}{r}.522^{* *} \\
.000 \\
50\end{array}$ \\
\hline $\begin{array}{l}\text { Konsumsi Masyarakat } \\
\text { (X) }\end{array}$ & $\begin{array}{l}\text { Pearson } \\
\text { Correlation } \\
\text { Sig. (2-tailed) } \\
\mathrm{N}\end{array}$ & $\begin{array}{r}.522^{* *} \\
.000 \\
50\end{array}$ & 50 \\
\hline
\end{tabular}

Correlation is significant at the 0.01 level (2-tailed).

Dari tabel diatas, terlihat angka koefisien korelasi sebesar $.522^{* *}$. Artinya besar korelasi antara variable Pendapatan masyarakat dan konsumsi masyrakat ialah sebesar 0,522 atau kuat karena mendekati angka 1. Tanda dua bintang $\left(^{* *}\right)$ artinya korelasi signifikan pada angka signifikansi sebesar 0,01 dan mempunyai kemungkinan dua arah (2-tailed). Di dasarkan pada criteria yang ada hubungan kedua variable signifkan sebesar $0,000<0,001$. (jika tidak ada tanda dua bintang, maka secara otomatis signifikasinya sebesar 0,05). Hubungan kedua variabel mempunyai dua arah (2-tailed), yaitu dapat searah dan tidak searah. 
Arah korelasi dilihat dari angka koefisien korelasi hasilnya positif dan negatif. Karena angka koefisien korelasi hasilnya positif, yaitu 0,522; maka korelasi kedua variabel bersifat searah. Maksudnya jika tingkat pendapatan masyrakat tinggi maka tingkat konsumsi masyarakat juga tinggi.

\section{PENUTUP}

\section{KESIMPULAN}

1. Berdasarkan hasil penelitian nilai koefisen korelasi atau nilai $r=0,522$ dimana $0,00<0,001$

2. Berdasarkan hasil analisi korelasi diperoleh penjelasan bahwa variabel pendapatan mempunyai hubungan yang kuat dengan tingkat konsumsi masyarakat dengan nilai koefisien korelasi sebesar 0,522.

3. Jika di lihat dari hipotesis maka hipotesis penelitian ini terbukti.

\section{SARAN}

1. Bagi masyarakat yang berpenghasilan rendah hendaknya mampu mengelola hasil pendapatannya seefektif mungkin, mengingat kebutuhan konsumsinya.

2. Untuk menutupi segala kekurangan yang ada hendaknya dapat mengambil langkah yang cukup strategis yaitu penghematan dan adanya pendapatan tambahan.

3. Untuk meningkatkan pendapatan masyrakat kiranya pemerintah membangun dan meningkatkan fasilitas - fasilitas umum serta sarana dan prasarana ekonomi dalam rangka meningkatkan taraf hidup masyarakat. 
Jurnal Ekonomi Balance Fakultas Ekonomi Dan Bisnis

Volume 11 No 1 Tahun 2015

\section{DAFTAR PUSTAKA}

Badan Pusat Statistik Kabupaten Gowa, 2011

Ferguson dalam juantin 2007. Faktor Pendapatan Masyarakat.

Kaslan. 2009. Besarnya pendapatan.

Partadiredja. 1985.Pengertian Konsumsi.http//www google.com.

Rosyidi, Suherman. 2007. Pengantar Teori Ekonomi, Pendekatan Kepada Teori

Mikro dan Makro, Edisi1, Jakarta : Raja Grafindo Persada

Sicat dan Arndt 2005. Pengeluaran konsumsi dan pendapatan masyarakat.

$\mathrm{http} / / \mathrm{www}$ google.com.

Sofyan. 2007. Tingkat Pendapatan dan Pemberian Bantuan Riil http// www google.com.

Sukirno, Sadono. 2007. Makro Ekonomi Modern. Jakarta : PT. Raja Grafindo Persada..

Suyanto, Nurhadi. 2006. Ekonomi SMP. Jakarta: Erlangga.

Winardi 2007 Pengetrian Penadapatan.http//I Indonesia. 